\title{
Genetic characterization of the Spanish Trotter horse breed using microsatellite markers
}

\author{
Pedro Javier Azor ${ }^{1}$, Mercedes Valera $^{2}$, María Dolores Gómez ${ }^{1}$, Félix Goyache ${ }^{3}$ and Antonio Molina ${ }^{1}$ \\ ${ }^{1}$ Departamento de Genética, Universidad de Córdoba, Córdoba, Spain. \\ ${ }^{2}$ Departamento de Ciencias Agroforestales, Universidad de Sevilla, Sevilla, Spain. \\ ${ }^{3}$ SERIDA-Somió, Gijón, Asturias, Spain.
}

\begin{abstract}
To assist in selection schemes we carried out the first genetic characterization of the Spanish Trotter horse (Trotador Español). We used 16 microsatellite markers to genotype 40 unrelated Spanish trotters, 25 native Balearic horses (11 Menorquina and 14 Mallorquina horses) and 32 Andalusian horses. The observed heterozygosity for the Spanish Trotters was $0.647 \pm 0.037$ and the expected heterozygosity was $0.696 \pm 0.026$ while the average number of alleles per locus was $6.0 \pm 0.341$, these values being similar to the data published for other horse breeds. We also tried to establish the importance of the Mallorquina and Menorquina breeds in the present Spanish Trotter population. Only $9 \%$ of the total genetic variability could be attributed to differences between breeds (mean $\left.F_{S T}=0.09 \pm 0.010\right)$. Recent migration rates were confirmed the low recent genetic relationship between the Balearic breeds and Spanish Trotters, indicating that the genetic background of the present Spanish Trotter population is not based on the native Balearic horse population.
\end{abstract}

Key words: horse, Spanish Trotter breed, microsatellites, genetic diferenciation, migration rates.

Received: November 28, 2005; Accepted: July 4, 2006.

\section{Introduction}

The Spanish Trotter horse (Equus caballus), also known in spanish language as Trotador Español, is a breed of increasing importance in Spain. The Gran Premio Nacional (Spanish national harness-race) is a Trotter horse race which is a prestigious event in the Spanish horse industry and is evidence of the importance of this breed.

The Spanish Trotter studbook was founded in 1980 and at present includes 15,510 horses (Azor et al., 2005; unpublished data). The Spanish Trotter population is mainly bred in the Balearic Islands of Majorca (Mallorca in Spanish), Minorca (Menorca in Spanish) and Ibiza, the latest census showing that $85 \%$ of the Spanish Trotter population is located in Majorca. Artificial insemination is the most frequent reproductive practice used in the breed, with semen mainly selected from French and American Trotter stallions. The foals with French or American Trotter stallions are registered in the Spanish Trotter studbook including the identification and the origin of the parent.

Historically, the Spanish Trotter breed was formed by mating native Balearic mares belonging to the Mallorquina

Send correspondence to Pedro Javier Azor. Departamento de Genética, Universidad de Córdoba, Edif. Mendel, PI. Baja, Campus de Rabanales, Ctra. N-IV, km 396, 14071 Córdoba, Spain. E-mail: ge2azorp@uco.es. breed from Majorca island and the Menorquina breed from Minorca with foreign stallions, mainly from Russian Orlov Trotters and French Trotters (Llamas et al., 1992). The Mallorquina and Menorquina breeds are two endangered horse populations included in the Food and Agricultural Organization of the United Nations (FAO) list of domestic animals to be protected FAO, http://dad.fao.org/es/home. htm.

The Mallorquina and Menorquina studbooks were founded in 1993 and the genetic admixture between them is considered important (Cañón et al. 2000). The Mallorquina studbook contains 247 horses while the Menorquina studbook contains 2,351 horses, although a census conducted in 2003 by the Spanish Ministry of Agriculture, Fisheries and Food "Estudio y caracterización del sector equino en España" (http://www.mapa.es/app/Equino/ documentos/Estudio $\% 20 \mathrm{y} \% 20$ Caracterización $\% 20 \mathrm{del} \% 2$ 0Sector\%20Equino\%20en\%20España.pdf) recorded only 172 Mallorquina and 1,647 Menorquina horses.

The Spanish Trotter Breeders Association (ASTROT) has recently implemented a selection scheme with the support of Spanish Ministry of Agriculture, Fisheries and Food and has tried to establish the importance of the native Balearic Mallorquina and Menorquina breeds in the present Spanish Trotter population. However, there 
have been only a few molecular studies of Iberian horses (Vila et al., 2001; Lopes et al., 2005; Royo et al., 2005 ) especially using microsatellites (Cañón et al., 2000) and in this context the molecular characterization of the Spanish Trotter breed would is important.

\section{Material and Methods}

\section{Sample collection and DNA isolation}

Tubes containing ethylenediaminetetraacetic acid (EDTA) were used to collect blood samples from 40 unrelated horses registered in the Spanish Trotter studbook. Genealogical information showed that the ancestry of 11 of the Spanish Trotters was more than 75\% American Trotter while that of a further 15 of the Spanish Trotters was more than $75 \%$ French Trotter. We also collected blood samples from 25 unrelated native Balearic horses (14 Menorquina and 11 Mallorquina). Blood samples were also collected from an outgroup of 32 Andalusian horses. Genomic DNA was extracted from whole blood using the salting out procedure of Miller et al. 1988.

\section{Microsatellite amplification}

Samples were genotyped for a set of 16 microsatellites (Table 1) recommended for paternity tests and in- dividual identification by the International Society for Animal Genetics (ISAG). Microsatellites were amplified using fluorescently-labeled primers (StockMarks ${ }^{\circledR}$ for horses, PE Applied Biosystems, Foster City, CA) following the PCR conditions given by Dimsoski (2003) and the PCR was run on a Mastercycler ${ }^{\circledR}$ ep gradient $S$ thermal cycler (Eppendorf, Germany) using $10 \mathrm{~min}$ at $95^{\circ} \mathrm{C}$ to activate the AmpliTaq Gold DNA polymerase followed by 30 cycles of $30 \mathrm{~s}$ at $95,{ }^{\circ} \mathrm{C}, 30 \mathrm{~s}$ at $60{ }^{\circ} \mathrm{C}$ and $60 \mathrm{~s}$ at $72{ }^{\circ} \mathrm{C}$, with a final extension of $60 \mathrm{~min}$ at $72{ }^{\circ} \mathrm{C}$. The PCR products were stored frozen until they were detected by capillary electrophoresis using an Applied Biosystems 3100 DNA sequencer. Allele sizes were determined after processing the raw data with the software packages GeneScan 3.7 and Genotyper 3.7 using a LIZ 500 bp internal size standard (Applied Biosystems).

\section{Statistical analysis}

The Genetix 4.2 program (Belkhir et al. 2001) was used to compute the following parameters across loci and populations: allele frequencies, number of alleles per locus, observed heterozygosity (Ho) and expected heterozygosity (He). This program was also used to compute Wright's F statistics $\left(\mathrm{F}_{\mathrm{ST}}, \mathrm{F}_{\mathrm{IS}}\right.$ and $\mathrm{F}_{\mathrm{IT}}$; Wright, 1965, 1978) in the form proposed by Weir and Cockerham (1984). The different

Table 1 - Total number alleles (k), observed ( $\mathrm{Ho})$ and expected heterozygosity $(\mathrm{He})$ and chromosome location of the microsatellites analyzed in the Spanish Trotter breed and in all the breeds analyzed.

\begin{tabular}{|c|c|c|c|c|c|c|c|}
\hline \multirow[b]{3}{*}{ Loci } & \multicolumn{2}{|c|}{ Total number alleles (k) } & \multicolumn{4}{|c|}{ Heterozygosity } & \multirow{3}{*}{$\begin{array}{l}\text { Chromosome } \\
\text { location }\end{array}$} \\
\hline & \multirow{2}{*}{$\frac{\text { Spanish Trotter }}{\mathrm{k}}$} & \multirow{2}{*}{$\frac{\text { Whole population }}{\mathrm{k}}$} & \multicolumn{2}{|c|}{ Spanish Trotter } & \multicolumn{2}{|c|}{ Whole population } & \\
\hline & & & Но & $\mathrm{He}$ & Ho & $\mathrm{He}$ & \\
\hline AHT4 & 5 & 8 & 0.675 & 0.686 & 0.694 & 0.754 & 24 \\
\hline AHT5 & 7 & 7 & 0.750 & 0.756 & 0.752 & 0.801 & A8 \\
\hline ASB17 & 7 & 12 & 0.775 & 0.791 & 0.717 & 0.839 & 2 \\
\hline ASB2 & 8 & 8 & 0.793 & 0.765 & 0.805 & 0.802 & 15 \\
\hline ASB23 & 6 & 6 & 0.658 & 0.757 & 0.611 & 0.789 & 3 \\
\hline CA425 & 6 & 8 & 0.514 & 0.697 & 0.510 & 0.698 & 28 \\
\hline HMS1 & 6 & 6 & 0.553 & 0.708 & 0.522 & 0.649 & 15 \\
\hline HMS2 & 7 & 8 & 0.839 & 0.802 & 0.837 & 0.809 & 10 \\
\hline HMS3 & 5 & 7 & 0.538 & 0.543 & 0.541 & 0.686 & 9 \\
\hline HMS6 & 5 & 6 & 0.842 & 0.731 & 0.743 & 0.763 & 4 \\
\hline HMS7 & 5 & 8 & 0.500 & 0.646 & 0.666 & 0.777 & 1 \\
\hline HTG10 & 8 & 11 & 0.571 & 0.707 & 0.729 & 0.871 & 21 \\
\hline HTG4 & 5 & 6 & 0.700 & 0.720 & 0.733 & 0.759 & 9 \\
\hline HTG6 & 4 & 6 & 0.650 & 0.628 & 0.571 & 0.676 & 15 \\
\hline HTG7 & 4 & 5 & 0.275 & 0.399 & 0.347 & 0.464 & 4 \\
\hline VHL20 & 8 & 9 & 0.725 & 0.793 & 0.670 & 0.837 & 30 \\
\hline All loci & 96 & 121 & 0.647 & 0.696 & 0.653 & 0.748 & \\
\hline
\end{tabular}

The 16 loci used were: AHT4, AHT5 (Binns et al. 1995); ASB17, ASB2, (Breen et al., 1997); ASB23 (Lear et al. 1999); UCDEQ425 (Eggleston-Stott et al., 1997); HMS1, HMS2, HMS6, HMS7 (Guerín et al, 1994); HTG4, HTG6 (Ellegren et al. 1992), HMS3, HTG7, HTG10 (Marklund et al., 1994); and VHL20 (Van Haeringen et al., 1994). 
F-statistics look at different levels of population structure. $\mathrm{F}_{\mathrm{IT}}$ is the inbreeding coefficient of an individual (I) relative to the total $(\mathrm{T})$ population, $\mathrm{F}_{\mathrm{IS}}$ is the inbreeding coefficient of an individual (I) relative to the subpopulation (S) and $\mathrm{F}_{\mathrm{ST}}$ is the effect of subpopulations (S) compared to the total population $(\mathrm{T})$, and is calculated by solving the equation $\left(1-F_{I S}\right)\left(1-F_{S T}\right)=\left(1-F_{I T}\right)$.

We also used the Genetix 4.2 program to compute the among population Reynolds' distance matrix (Reynolds et al. 1983) and the effective number of migrants per generation (Nm; Wright, 1969). The number of migrants per generation $(\mathrm{Nm})$ can be interpreted as the upper limit of the number of migrants per generation allowing for the maintenance of the observed genetic differentiation between the breeds, the more divergent the populations the lower the $\mathrm{Nm}$ value, (Slatkin, 1985). Individual multilocus genotypes were also investigated by carrying out a factorial analysis of correspondences to obtain an unbiased test of population structure.

Recent migration rates among populations were estimated using the BayesAss + program (Wilson and Rannala, 2003). This method puts less emphasis on some key assumptions from previous assignment methodologies, namely that genotypes are in Hardy-Weinberg equilibrium within populations. The program simultaneously estimates the probability distribution of allelic frequencies for each locus and migration rates between populations $(m)$, assessing the relative importance of specific patterns of population dynamics. The BayesAss + program was ran using a burning and a data collection period of $3 \times 10^{6}$ iterations.

\section{Results}

\section{Genetic diversity}

Parameters characterizing the polymorphism of the microsatellite set used are given in Table 1. A total of 121 alleles were detected across the 16 loci analyzed. The number of alleles per marker varied from 5 for HTG7 to 12 for ASB17 and the across loci Ho value ranged from 0.347 for HTG7 to 0.837 for HMS2 while the He value varied from 0.464 for HTG7 to 0.871 for HTG10. The heterozygosity values for the whole dataset were 0.653 for Ho and 0.748 for He. The average number of alleles per locus ranged from $4.5 \pm 0.532$ for the Mallorquina breed to $6.0 \pm 0.341$ for the Spanish Trotters, while the highest heterozygosity values $(\mathrm{Ho}=0.729 ; \mathrm{He}=0.725)$ were shown by the Menorquina horses and the lowest values $(\mathrm{Ho}=0.618$; $\mathrm{He}=0.613$ ) by the Andalusian horses (Table 2). The $\mathrm{F}_{\mathrm{IS}}$ value varied from 0.051 for the Menorquina horses to 0.113 for the Mallorquina horses, demonstrating a clear heterozygote deficiency for all the breeds analyzed.

\section{Population structure}

The F-statistics values for the whole population (i.e. Spanish Trotters + native Balearic + Andalusian) were $\mathrm{F}_{\mathrm{IS}}=0.085 \pm 0.022, \quad \mathrm{~F}_{\mathrm{IT}}=0.167 \pm 0.022$ and $\mathrm{F}_{\mathrm{ST}}=0.090 \pm 0.010$. Differentiation between breeds was estimated using Reynolds' distance, the values of which varied from 0.001 for the Menorquina-Mallorquina pair to 0.126 for the Mallorquina-Andalusian pair (Table 3). Table 3 shows that the highest effective number of migrants per generation $(\mathrm{Nm}=170.16)$ was between the MenorquinaMallorquina pair, which was very high in comparison to the values for the Mallorquina-Spanish Trotter pair $(\mathrm{Nm}=1.94)$ and the Mallorquina-Andalusian pair $(\mathrm{Nm}=1.86)$.

Regarding the analysis of the individual horses, factorial analysis of correspondence identified three factors with an eigenvalue $=1$ explaining $84.17 \%$ of the total variance. Figure 1 gives a plot showing the location of the analyzed horses in the bi-dimensional space formed by the two first factors (explaining, respectively $37.24 \%$ and $26.45 \%$ of the total variance). The $\mathrm{X}$-axis dimension clearly differentiates

Table 3 - Reynolds distance Matrix (upper diagonal) and effective number of migrants per generation ( $\mathrm{Nm}$, lower diagonal) for the four breeds analyzed.

\begin{tabular}{lrccc}
\hline & Mallorquina & Menorquina & $\begin{array}{c}\text { Spanish } \\
\text { Trotter }\end{array}$ & $\begin{array}{c}\text { Andalusian } \\
\text { Horse }\end{array}$ \\
\hline Mallorquina & & 0.001 & 0.121 & 0.126 \\
Menorquina & 170.16 & & 0.062 & 0.080 \\
Spanish Trotter & 1.94 & 3.82 & & 0.093 \\
Andalusian Horse & 1.86 & 2.98 & 2.55 & \\
\hline
\end{tabular}

Table 2 - Number of samples (N), average number alleles per locus and breed (k), observed (Ho) and expected heterocygosity (He) and $\mathrm{F}_{\mathrm{IS}}$.parameter.

\begin{tabular}{lccccc}
\hline Population & $\mathrm{N}$ & $\mathrm{k}$ & \multicolumn{2}{c}{ Heterocygosity $( \pm \mathrm{SE})^{\mathrm{a}}$} & \multirow{2}{*}{$\mathrm{F}_{\mathrm{IS}} \pm \mathrm{SE}$} \\
\cline { 4 - 5 } & & & Observed $\pm \mathrm{SE}$ & Expected $\pm \mathrm{SE}$ & \\
\hline Mallorquina & 11 & $4.5 \pm 0.532$ & $0.649 \pm 0.071$ & $0.604 \pm 0.542$ & $0.113 \pm 0.059$ \\
Menorquina & 14 & $5.7 \pm 0.309$ & $0.729 \pm 0.042$ & $0.725 \pm 0.019$ & $0.051 \pm 0.045$ \\
Spanish Trotter & 40 & $6.0 \pm 0.341$ & $0.647 \pm 0.037$ & $0.695 \pm 0.026$ & $0.091 \pm 0.032$ \\
Andalusian & 32 & $5.1 \pm 0.543$ & $0.618 \pm 0.060$ & $0.613 \pm 0.044$ & $0.096 \pm 0.038$ \\
Horse & & & & & \\
\hline
\end{tabular}

${ }^{\mathrm{a}}$ Standard error. 


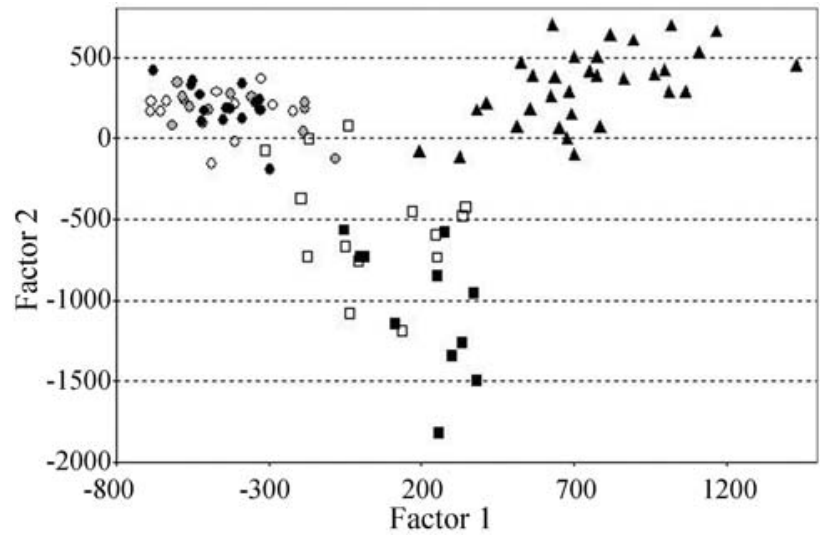

Figure 1 - Correspondence analysis using individual multilocus genotypes in the Spanish horse breeds analyzed. Individual Andalusian horses are represented by triangles, Mallorquina horses by black squares and Menorquina horses by open squares. Spanish Trotter horses of American Trotter ancestry are shown by gray circles, those of French Trotter ancestry by black circles and those with less than $75 \%$ of their ancestors from American and French Trotter horses by open circles.

the Andalusian horses from the rest while the Y-axis dimension separates the Spanish Trotter and Balearic horses, with the Balearics showing no clear differentiation between breeds. Estimates of recent migration rates between populations (up to the second generation of migrants) are shown in Table 4. Three of the breeds (Spanish Trotter, Menorquina, and Andalusian) have not received a significant proportion of migrants. Significant recent introgression rates (approximately 30\%) were found for the Menorquina breed to Mallorquina breed. Average standard deviations of all distributions of $m$ for each source population ranged from 0.004 to 0.048 .

\section{Discussion}

During the research described in this paper we carried out the first genetic analysis of the Spanish Trotter breed using DNA markers. The polymorphism of the microsatellites reported in the literature for other horse breeds mostly range from 0.66 to 0.75 for Ho and from 0.64 to 0.77

Table 4 - Means of the posterior distribution of the estimated migration rates $(m)$ for each population using the BayesAss + program. The rows show the origins of the migrants while the columns show the populations which individual horses are migrating to (derived populations). Values on the diagonal are the proportion of individuals derived from the source populations for each generation. Contributions higher than 0.10 are in bold.

\begin{tabular}{lcccc}
\hline & \multicolumn{4}{c}{ Derived population } \\
\cline { 2 - 5 } $\begin{array}{l}\text { Parental } \\
\text { population }\end{array}$ & Mallorquina & Menorquina & $\begin{array}{c}\text { Spanish } \\
\text { Trotter }\end{array}$ & $\begin{array}{c}\text { Andalusian } \\
\text { Horse }\end{array}$ \\
\hline Mallorquina & $\mathbf{0 . 6 9 6 3}$ & 0.0218 & 0.0029 & 0.0105 \\
Menorquina & $\mathbf{0 . 2 6 8 0}$ & $\mathbf{0 . 8 9 5 3}$ & 0.0027 & 0.0302 \\
Spanish Trotter & 0.0179 & 0.0658 & $\mathbf{0 . 9 9 1 3}$ & 0.0149 \\
Andalusian Horse & 0.0176 & 0.0169 & 0.0029 & $\mathbf{0 . 9 4 4 3}$ \\
\hline
\end{tabular}

for He (Wimmers et al., 1998; Bjørnstad et al., 2000; Cañón et al., 2000; Cunnnigham et al., 2001; Luís et al., 2002; Aberlé et al., 2004; Achmann et al., 2004; Galov et al., 2005; Royo et al., 2005 ), although these values are not directly comparable with those detected by us because of differences in the microsatellite sets used.

The breeds analyzed by us showed strong heterozygote deficiency, characterized by high and positive $\mathrm{F}_{\mathrm{IS}}$ values. Gómez et al. (2005) have pointed out that Spanish Trotters are under high selection pressure for racing performance while Valera et al. (2005) has reported that the Andalusian breed is under selection pressure for morphological traits. The frequent use of semen from selected foreign studs in the Spanish Trotter breed is also significant (Azor et al., 2005; unpublished data).

The overall $F_{S T}$ value for our whole data set was similar to but slightly higher than the $7.8 \%$ reported by Cañón et al., (2000) for seven Spanish horse breeds (Asturcón, Caballo Galego, Losina, Pottoka, Jaca Navarra, Mallorquina and Menorquina) and the Thoroughbreds used as outgroup. However, our $F_{S T}$ value was slightly smaller than that found in some other studies, such as the $10 \%$ reported by Zabek et al. (2005) for some Polish breeds (Bilgoraj, Malopolski and Thoroughbreds), the $10.9 \%$ reported by Díaz et al., (2002) for the Argentine Creole and Thoroughbreds and the 11.7\% reported by Lippi and Mortari (2003) for two Brazilian breeds (Mangalarga Marchador and Mangalarga). It has been pointed out by some authors that the typical high within-population variability of microsatellites may result in low differentiation values (Hedrick, 1999; Balloux and Lugon-Moulin, 2002). Thus, the order of magnitude of genetic differentiation between breeds assessed by $\mathrm{F}_{\mathrm{ST}}$ estimators seems to be always low and rather constant regardless of the species (MacHugh et al. 1998; Laval et al., 2000; Arranz et al., 2001).

We estimated short-term differentiation between breeds using Reynolds' distance, which has been shown to be an appropriate measure for livestock populations with short-term divergence (Reynolds et al., 1983; Laval et al., 2002; Álvarez et al., 2005).

As expected, the highest distance values in our study were for the Andalusian outgroup. The Spanish Trotters was more distant from the Mallorquina sample than from the Menorquina sample, which does not agree with the main geographical location of the populations in that $85 \%$ of the Spanish Trotter population is located in Majorca, the home of the Mallorquina breed.

In general, the $\mathrm{Nm}$ values for the Spanish Trotters paired with the other breeds were higher than for the Andalusian horses paired with the other breeds and this highlights the weak genetic relationship in recent times between Spanish Trotters and the native Balearic horses, contrasting with the high genetic relationships $(N m=170.16)$ between the Mallorquina and Menorquina native Balearic breeds. 
However, the $\mathrm{Nm}$ gene flow estimator is derived from simplified models of population structure that assume constant population sizes, symmetrical migration at constant rates and population persistence for periods sufficient to obtain genetic equilibrium (Slatkin, 1985) and that probably do not agree with the scenario analyzed in this study. There is a need to apply new and more informative methodologies to establish the evolutionary history of present populations both in the long term flow of genes and in the recent patterns of migration (Wilson and Rannala, 2003). The recent migration rates estimated using the BayesAss + program (0.0029 and 0.0027) support the low recent genetic relationship between Spanish Trotters and the native Balearic breeds sampled. These values of $m$ were closed to zero and no significant. For individual horses this situation was also demonstrated by the correspondence analysis that enabled individual horses to be assigned without much uncertainty to their corresponding breeds, or, in the case of the native Balearic horses, breed group. However, correspondence analysis did not enable individual Spanish trotters to be distinguished according to their French or American origin.

Summarizing the information above, we can conclude that although originally the Spanish Trotter could have had a genetic background from Balearic native horses, it has been confirmed that recent generations have not been influenced by the native Balearic horses. However, further analysis will be needed to establish the level of genetic differentiation between the Spanish Trotter horse breed and other international Trotter breeds.

\section{Acknowledgments}

This study was partially financed by the Asociación de Criadores y Propietarios de Caballos Trotadores (ASTROT). The authors thank the breeders associated into Asociación Nacional de Criadores de Caballos de Pura Raza Española (ANCCE) and Asociación de Criadores y Propietarios de Caballos de Raza Mallorquina (AECAB$\mathrm{Ma}$ ) and Asociación de Criadores y Propietarios de Caballos de Raza Menorquina (ACPCRMe) for kindly providing blood samples.

\section{References}

Aberle KS, Hamann H, Drögemüller C and Distl O (2004) Genetic diversity in German draught horse breeds compared with a group of primitive, riding and wild horses by means of microsatellite DNA markers. Anim Genet 35:270-277.

Achmann R, Curik I, Dovc P, Kavar T, Bodo I, Habe F, Marti E, Sölkner J and Brem G (2004) Microsatellite diversity, population subdivision and gene flow in the Lipizzan horse. Anim Genet 35:285-292.

Álvarez I, Gutiérrez JP, Royo LJ, Fernández I, Gomez E, Arranz JJ and Goyache F (2005) Testing the usefulness of the molecular coancestry information to assess genetic relation- ships on livestock using a set of Spanish sheep breeds. J Anim Sci 83:737-744.

Arranz JJ, Bayón Y and San Primitivo F (2001) Differentiation among Spanish sheep breeds using microsatellites. Genet Sel Evol 33:529-542.

Balloux F and Lugon-Moulin N (2002) The estimation of population differentiation with microsatellite markers. Mol Ecol 11:155-165.

Belkhir K, Borsa P, Chikhi L, Raufaste N and Bonhomme F (2001) GENETIX 4.02, logiciel sous Windows TM pour la génétique des populations. Laboratoire Génome, Populations, Interactions CNRS UMR 5000, Université de Montpellier II, Montpellier, France.

Binns MM, Holmes NG, Holliman A and Scott AM (1995) Identification of polymorphic microsatellite loci in the horse and their use in Thoroughbred parentage testing. Br Vet $\mathrm{J}$ 151:9-15.

Bjørnstad G, Gunby E and Røed KH (2000) Genetic structure of Norwegian horse breeds. J Anim Breed Genet 117:307-317.

Breen M, Lindgren G, Binns MM, Norman J, Irvin Z, Bell K, Sandberg K and Ellegren H (1997) Genetical and physical assignments of equine microsatellites. First integration of anchored markers in horse genome mapping. Mamm Genome 8:267-273

Cañón J, Checa ML, Carleos C, Vega-Pla JL, Vallejo M and Dunner S (2000) The genetic structure of Spanish Celtic horse breeds inferred from microsatellite data. Anim Genet 31:39-48.

Cunningham EP, Dooley JJ, Splan RK and Bradley DG (2001) Microsatellite diversity, pedigree relatedness and the contributions of founder lineages to thoroughbred horses. Anim Genet 32:360-364.

Díaz S, Dulout FN and Peral-García P (2002) Greater genetic variability in Argentine Creole than in Thoroughbred horses based on serum protein polymorphisms. Genet Mol Res $1: 261-265$.

Dimsoski P (2003) Development of a 17-plex microsatellite polymerase chain reaction kit for genotyping horses. Croat Med J 44:332-335.

Eggleston-Stott ML, DelValle A, Bautista M, Dileanis S, Wictum E and Bowling AT (1997) Nine equine dinucleotide repeats at microsatellite loci UCDEQ136, UCDEQ405, UCDEQ412, UCDEQ425, UCDEQ437, UCDEQ467, UCDEQ487, UCDEQ502 and UCDEQ505. Anim Genet 28:370-371.

Ellegren H, Johansson M, Sandberg K and Anderson L (1992) Cloning of highly polymorphic microsatellites in the horse. Anim Genet 23:133-142.

Galov A, Byrne K, Duras-Gomercic M, Gomercic T, Nushol Z, Vincek D, Kocijan I, Tadic Z, Benkovic V, Baic I and Funk SM (2005) Effectiveness of nine polymorphic microsatellite markers in parentage testing in Posavina, Croatian Coldblood and Lipizzaner horse breeds in Croatia. Livest Prod Sci 93:277-282.

Gómez MD, Moll P, Roca B, Azor PJ and Valera M (2005). Sistemas de valoración genética del caballo Trotador en Europa. Med Mil 61:228-230.

Guérin G, Bertaud M and Amigues Y (1994) Characterization of seven new horse microsatellites: HMS1, HMS2, HMS3, HMS5, HMS6, HMS7 and HMS8. Anim Genet 25:62. 
Hedrick PW (1999) Highly variable loci and their interpretation in evolution and conservation. Evolution 53:313-318.

Laval G, Iannuccelli N, Legault C, Mlan D, Groenen MAM, Giuffra E, Andersson L, Nissen PE, Jørgenssen CB, Beeckmann P, Geldermann H, Foulley JL, Chevalet C and Ollivier L (2000). Genetic diversity of eleven European pig breeds. Genet Sel Evol 32:187-203.

Laval GM, SanCristobal and Chevalet C (2002). Measuring genetic distances between breeds: Use of some distances in various short term evolution models. Genet Sel Evol 34:481-507.

Lear TL, Brandon R and Bell K (1999) Physical mapping of ten equine di-nucleotide repeat microsatellites. Anim Genet 30:235.

Lippi AS and Mortari N (2003) Studies of blood groups and protein polymorphisms in the Brazilian horse breeds Mangalarga Marchador and Mangalarga (Equus caballus). Genet Mol Biol 26:431-434.

Llamas J, Castelló JI, Antón D and García J (1992). La Cría Caballar en España. Ed. Darley S.A., Barcelona, 231 pp.

Lopes MS, Mendonça D, Cymbron T, Valera M, da Costa-Ferreira J and da Câmara Machado A (2005) The Lusitano horse maternal lineage based on mitochondrial D-loop sequence variation. Anim Genet 36:196-202.

Luís C, Cothran EG and Oom MM (2002) Microsatellites in portuguese autochthonous horse breed: Usefulness for parentage testing. Genet Molec Biol 25:131-134.

MacHugh DE, Loftus RT, Cunningham P and Bradley DG (1998) Genetic structure of seven European cattle breeds assessed using 20 microsatellite markers. Anim Genet 29:333-340.

Marklund S, Ellegren H, Eriksson S, Sandberg K and Andersson L (1994) Parentage testing and linkage analysis in the horse using a set of highly polymorphic microsatellites. Anim Genet 25:19-23.

Miller S, Dykes D and Polesky HF (1988) A simple salting out procedure for extracting DNA from human nucleated cells. Nucleic Acid Research 16:1215.

Reynolds J, Weir BS and Cockerham CC (1983) Estimation of the coancestry coefficient basis for a short-term genetic distance. Genetics 105:767-779.

Royo LJ, Álvarez I, Beja-Pereira A, Molina A, Fernández I, Jordana J, Gómez E, Gutiérrez, JP and Goyache F (2005a)
The origins of Iberian horses assessed via mitochondrial DNA. Journal of Heredity 96:663-669.

Royo LJ, Álvarez I, Fernández I, Gutiérrez JP, Martínez JL, Gómez E and Goyache F (2005b) Análisis preliminar de dos poblaciones de Poni Céltico de Asturias usando marcadores microsatélites. XI Jornadas de Producción Animal (AIDA), ITEA, 26:72-74.

Slatkin M (1985) Rare alleles as indicators of gene flow. Evolutions 39:53-65.

Valera M, Molina A, Gutiérrez JP, Gómez J and Goyache F (2005) Pedigree analysis in the Andalusian horse: Population structure, genetic variability and influence of the Carthusian strain. Livest Pro Sci 95:57-66.

Van Haeringen H, Bowling AT, Scott ML, Lenstra JA and Zwaagstra KA (1994) A highly polymorphic horse microsatellite locus: VHL20. Anim Genet 25:207.

Vila C, Leonard JA, Gotherstrom A, Marklund S, Sandberg K, Liden K, Wayne RK and Ellegren H (2001) Widespread origins of domestic horse lineages. Science 291:474-477.

Weir BS and Cockerham CC (1984) Estimating F-statistics for the analysis of population structure. Evolution 38:1358-1370.

Wilson GA and Rannala B (2003) Bayesian inference of recent migration rates using multilocus genotypes. Genetics 163:1177-1191.

Wimmers K, Ponsuksili S, Schmoll F, Hardge T, Hatzipanagiotou A, Weber J, Wostmann S, Olik K and Schellander K (1998) Efficiency of microsatellite markers of the international standard panel for parentage control in German horse population. Zuchtungskunde 70:233-241.

Wright S (1965) The interpretation of population structure by F-statistics with special regard to systems of mating. Evolution 19:295-420.

Wright S (1969) Evolution and the Genetics of Populations. v. 2: The Theory of Gene Frequencies. University of Chicago Press, Chicago, 511 pp.

Wright S (1978) Evolution and the Genetics of Populations. v 4: Variability Within and Among Natural Populations. University of Chicago Press, Chicago, 580 pp.

Zabek T, Nogaj A, Radko A, Nogaj J and Slota E (2005) Genetic variation of Polish endangered Bilgoraj horses and two common horse breeds in microsatellite loci. J Appl Genet 46:299-305.

Associate Editor: Pedro Franklin Barbosa 